Madalena Colaço \& Gabriela Matos,

"Explicative clauses in Portuguese as a case of parentheses" (accepted)

To be published in (2016)

Romance Languages and Linguistic Theory 10,

Selected papers from 'Going Romance' 28.

Edited by:

Ernestina Carrilho,

Alexandra Fiéis,

Maria Lobo and

Sandra Pereira.

Amsterdam / Philadelphia: John Benjamins.

ISBN: 9789027203908

ISBN: 9789027266415

(Е-ВООК) 


\title{
Explicative clauses in portuguese as a case of parentheses*
}

\author{
Madalena Colaço \& Gabriela Matos \\ Faculdade de Letras da Universidade de Lisboa / Centro de Linguística da \\ Universidade de Lisboa
}

\begin{abstract}
A subset of causal explicative clauses in European Portuguese (EP) introduced by the connectors pois 'for', que 'that' and porque 'because' has been classified either as coordinate or subordinate clauses, or alternatively as autonomous discursive expressions. Extending previous work, we claim that, although the sentences they head present most of the characteristics of subordination, they establish with the host sentence a paratactic link, and involve secondary and non-restrictive information. We will argue that these explicative clauses arise from parenthetical inclusion via Par-Merge, in the sense of de Vries (2012). This analysis allows us to provide a syntactic account for these clauses, and to capture some of their correlated discursive properties.
\end{abstract}

Keywords: Causal explicative clauses; parenthetical clauses; parataxis; subordination; Parenthetical Merge

\section{Introduction}

In European Portuguese (henceforth EP), some causal explicative clauses headed by the connectors pois 'for', porque 'because' and que (this one glossed as 'that' but interpreted as 'because') have been classified in the literature as coordinate or subordinate clauses, or as discursive elements that may not be captured within the sentence grammar and must be conceived as autonomous text units.

\footnotetext{
* The research presented in this paper has been funded by the FCT project UID/ LIN/00214/2013.

We would like to thank the audience of Going Romance 2014, and especially two anonymous reviewers, for helpful comments on a previous version of this work.
} 
(1) Hoje vai chover, que o país está em alerta amarelo. today will rain, that the country is in warning yellow 'Today it will rain, because the country is on yellow warning.'

(2) Ela saiu de casa à pressa, pois as luzes estão acesas. she left of home in.the hurry, for the lights are lighted 'She left home in a hurry, for/because the lights are on.'

(3) A Maria está triste, porque está muito calada. the Maria is sad, because is very quiet 'Maria is sad, because she is very quiet.'

In this work we will claim that these clauses in EP, in spite of presenting most of the morphosyntactic properties of subordination, establish with the sentence they are related to a paratactic link which arises from a syntactic connection obtained by parenthetical inclusion via par-Merge, in the sense of de Vries (2012).

The current work differs from the previous ones in that it provides empirical evidence for the parenthetical status of the explicative clauses under study and shows that they have a wider range of distribution than usually assumed. It also shows that these explicatives are adequately analyzed as an instance of parentheses.

The paper is structured as follows: in Section 2, we delimit the subject of our study, regarding the empirical coverage of causal and explicative clauses; in Section 3 , we mainly present the core arguments that have been adduced in the literature to classify the explicative clauses introduced by pois 'for', que 'that' and porque 'because' as coordinate or subordinate sentences; in Section 4, we present evidence for the parenthetical status of these explicative clauses; in Section 5, we discuss two recent proposals to deal with parentheticals, briefly presenting their problems and advantages; Section 6 argues for the analysis of the explicative clauses under study in terms of parenthetical inclusion; Section 7 explores the correlation between the position of the explicative clause and their discursive value; finally, Section 8 summarizes the most relevant conclusions of this study.

\section{Explicative versus causal clauses}

Studies on causal clauses categorize them into two major subclasses considering their semantic value: proper causal clauses conveying the direct reason (e.g. Quirk et al. 1985), or the real or inferred cause (Lobo 2013), of the situation denoted by the main clause, and causal clauses expressing the motive underlying the utterance of the proposition they are related with. The latter clausal clauses are sometimes called clauses of indirect reason (Quirk et al. 1985) or of definitional cause 
(Giusti 1991). Most classical analyses had subsumed this classification under the distinction between causal clauses, like (4), which denote the real cause of the main clause (de re cause), and explicative clauses, like (1)-(3), which justify the utterance of the main proposition (de dicto cause) (e.g. Bello 1847 for Spanish; Lobo 2003, 2013 and Macário Lopes 2012 for European Portuguese).

(4) Hoje nevou porque a temperatura desceu abaixo dos $0^{0} \mathrm{C}$. today snowed because the temperature dropped below of the $0^{0} \mathrm{C}$. 'It snowed today because the temperature dropped below $0^{0} \mathrm{C}$ '.

Thus, while the sentence in (4) is adequately paraphrased by (5a) instead of (5b), the sentence in (1) must be assigned the paraphrase (6a) rather than (6b):

(5) a. It snowed today. The reason is that the temperature dropped below $0^{0}$ Celsius.

b. \#It snowed today. I say that because the temperature dropped below $0^{0}$ Celsius.

(6) a. Today it will rain. I say that because the country is in yellow warning.

b. \#Today it will rain. The reason is that the country is in yellow warning.

However, taking into account the kind of connectors that introduce each one of these types of clauses, it has been remarked that the connectors presenting an explicative import may also head clauses that denote the real or inferred cause of the state of affairs expressed in the main clause (see, for instance, for Spanish, Santos Río 1982 and Galán-Rodriguez 1999, and for Portuguese, Said Ali 1931, Cunha and Cintra 1984, Matos 2004, Lopes 2004, Lobo 2013 and Colaço and Matos 2015). In Portuguese, the explicative connectors comprise pois 'for', que 'that' and porque 'because', but are not restricted to them and include other connectors, such as já que 'since' or uma vez que 'once' (see Lobo 2003, 2013), as exemplified in (7) for uma vez que:

(7) Hoje nevou, pois/quel porquel uma vezque a temperatura today snowed, for/that/ because/ once the temperature desceu abaixo dos $0^{0} \mathrm{C}$. dropped below of the $0^{0} \mathrm{C}$

'It snowed today, because the temperature dropped below $0^{0} \mathrm{C}$ '

Being aware of this problem, in the current paper, we will restrict our analysis to explicative clauses introduced by pois, que and porque, and we will only consider the cases where the explicative clause clearly provides a de dicto reading, as in (1) to (3). 
In our approach, we will mainly concentrate on the syntactic properties of these explicatives, although some consequences regarding their discourse properties will be drawn.

\section{The conflicting properties of explicative clauses}

Across languages, some specific causal connectors have been characterized as coordinate or subordinate conjunctions on the basis of the semantic, pragmatic and syntactic properties of the sentences they introduce and the connection they establish with the related clause. ${ }^{1}$ Thus, in Romance languages, French car 'because' has been classified as a coordinate conjunction, while parce que 'because' (Grevisse-Goosse 1993) has been assumed as a complementizer, although it has also been recognized that sometimes the behavior of car and parce que is not radically distinct (Grevisse-Goosse, 1993:376, $261,2^{0} ; 1554, \$ 1038$ ) and car shares several properties with other subordinators, for instance puisque 'since' (Piot 1988).

Also, depending on the significance assigned by the authors to the distinct behavior of causal clauses, the same causal explicative connectors have been classified either as coordinators or subordinators. This is the case of Spanish pues 'for' and porque 'because', which were assumed as coordinative conjunctions in RAE (1931) and as subordinative connectors in RAE (1973) and in Galán-Rodriguez (1999).

Similarly, in Portuguese, pois, que and porque have been classified both as coordinative and as subordinative conjunctions, depending on the linguistic contexts where they occur (Said Ali 1931, Cunha and Cintra 1984), or as complementizers (Bechara 1999, Matos 2003, 2004, Matos and Raposo 2013).

In favor of their coordinative status, it has been crucially claimed that the explicative clauses they introduce present a looser link with the connected sentence than causal clauses (Said Ali 1931, Cunha and Cintra 1984), may not be fronted and, at least those introduced by pois, do not easily accept coordination (Lopes 2004, Lobo 2013, Matos and Raposo 2013).

1. There is much work published on this subject in other languages, namely Germanic languages. In this paper we mainly concentrate on Portuguese, a Romance language. However, we admit that a comparative study of clausal explicative clauses in Portuguese and V2 Germanic languages could be an important move to a better understanding of the properties of these clauses. We leave this study for future work. 
(8) a. Ela saiu de casa à pressa, pois/que/porque as luzes she left of home in.the hurry, for/that/because the lights estão acesas.

are lighted

'She left home in a hurry, for/because the lights are on.'

b. ${ }^{*}$ Pois/*que/\#porque as luzes estão acesas, ela saiu for/ that/ because the lights are lighted, she left

de casa à pressa.

of home in.the hurry

c. ??Eles estão em casa, pois o carro está na garagem they are at home, for the car is in.the garage e pois as luzes estão acesas. and for the lights are lighted

However, explicatives headed by pois, que and porque present most of the properties of subordinate clauses (Matos 2004, Matos and Raposo 2013). In fact, like conjunctional complementizers, and in opposition to coordinate conjunctions, they only introduce finite clauses, as shown by the contrast in (9) vs. (10):

(9) a. Eles dizem que estão tristes, pois/ porque estão cansados. they say that are sad, for / because are tired 'They say that they are sad, because they are tired.'

b. ${ }^{\star}$ Eles dizem estar tristes, pois/ porque estar cansados. they say be.Inf sad, for / because be.Inf tired

(10) a. Eles dizem que estão tristes e que estão cansados they say that are sad, and that are tired 'They say that they are sad and that they are tired.'

b. Eles dizem estar tristes e estar cansados. they say be.INF sad, and be.INF tired 'They say to be sad and (to be) tired.'

Also explicative connectors only select TP; hence, they do not connect constituents below the sentence level, in opposition to coordinative conjunctions, as illustrated in (11) and (12), where APs occur:

(11) ${ }^{\star}$ Eu estou irascível, pois/porque/que esfomeada.

I am irascible, for/because/that hungry

(12) Eu estou irascível e esfomeada.

I am irascible and hungry

'I am irascible and hungry'. 
Furthermore, pois, que and porque may not connect CPs, i.e. sentences headed by overt complementizers, in contrast with what happens with regular coordinators:

(13) *Eles estão em casa, já que o carro está na garagem they are at home, since the car is in.the garage pois/ quel porque umavezque as luzes estão acesas. for/ that/ because once the lights are lighted

(14) Eles estão em casa, já que o carro está na garagem they are at home, since the car is in.the garage e uma vezque as luzes estão acesas. and once the lights are lighted.

'They are at home, since the car is in the garage and given that the lights are on.'

Like subordinate sentences headed by overt complementizers, and in contrast with coordinate sentences, explicative clauses do not allow gapping in EP, as illustrated in (15) and (16):

(15) ${ }^{\star} A$ Paula está em casa, pois/ porque/que o cão_ the Paula is at home, for/ because/that the dog na casota.

in.the doghouse

(16) A Paula está em casa e o cão _ na casota. the Paula is at home and the dog _ in.the doghouse 'Paula is at home and his dog in the doghouse.'

In addition, explicative clauses differ from coordination because they do not allow across-the-board movement, as shown in (17):

a. Ela comprou um carro novo, pois/ que/porque eu vi she bought a car new for/ that/because I saw um carro novo na garagem.

a car new in.the garage

'She bought a new car, because I saw a new car in the garage.'

b. ??O que é que ela comprou $[-]_{i}$, pois/que/porque eu the what is that she bought $[-]_{i}$ for/that/because I

vi $[-]_{i}$ na garagem?

saw [-] in.the garage

'What did she buy, because I saw in the garage?'

In sum, to some extent, explicative clauses in EP seem to be adequately characterized as subordinate clauses (Matos 2003, 2004, Matos and Raposo 2013). However, 
the relative autonomy of the explicative clause regarding the connected sentence must be accounted for. This property has been noticed by several authors, who claimed that explicative clauses express an independent thought (e.g. Said Ali 1931), that they are non-integrated sentences (Matos \& Raposo 2013), or even that they are independent discourse fragments, since they do not participate in the predication of the related sentence (Peres and Mascarenhas 2006, Macário Lopes 2012).

\section{Explicative clauses in European Portuguese as parentheticals}

Despite presenting most of the properties of subordinate sentences, explicative clauses in EP establish a paratactic link with the clause they are related to. They behave as non-integrated sentences and may be characterized as parentheticals.

In fact, explicative clauses in EP share with other parentheticals (cf. Déhé and Kavalova 2007, Matos and Colaço 2010, de Vries 2012, a.o.) crucial properties.

From a structural point of view, parentheticals are loosely connected with their hosts. ${ }^{2}$ Also, their content often allows their occurrence in different positions of the host sentence, then resulting what has been called floating parentheticals. Explicative clauses also present this property, although it has remained unnoticed in the literature on EP:

(18) O João era incapaz de tal atitude, pois/que/porque eu the João was incapable of such attitude, for/that/because I conheço-o bem. know him.CL well 'João would be incapable of such an attitude, because I know him well.'

O João, pois/ que/ porque eu conheço-o bem, the João, for/ that/ because I know him.CL well

era incapaz de tal atitude. was incapable of such attitude.

'João, because I know him well, would be incapable of such an attitude.'

Parentheticals have their own prosody. When they are right appended, they do not affect the intonation of the host. When they are interpolated, they produce a

2. As we will see in Section 5, there is more than one proposal to account for the loose relation that a parenthetical constituent establishes with its host. 
prosodic break in the host sentence (Frota 2000, Déhé and Kavalova 2007). Explicative clauses behave alike. In correlation, the written counterparts of the explicatives are always isolated from their host sentences by commas:

(20) O Pedro está constipado, pois/que/porque espirrou durante the Pedro is cold, for/that/because sneezed during todo o dia. all the day

'Pedro got a cold, for/because he sneezed all day long.'

(21) O Pedro alugou a casa, pois/quel porque tenho visto the Pedro rent the house, for/that/ because have seen as janelas abertas, aos seus amigos franceses. the windows open, to.the his friends French 'Pedro rent his house, because I have seen the windows open, to his French friends.'

A parenthetical expression has semantic autonomy with respect to its host. Explicative clauses show the same semantic behavior: their meaning does not affect the meaning of the host sentence, as shown in sentences like (18)-(21).

In fact, parentheticals add extra information: as for other cases of parenthesis, they always correspond to secondary information (de Vries 2012, Kluck 2015). The same occurs with explicative clauses, which are speaker-oriented and supply an explanation or a justification about the motive of the utterance of the proposition corresponding to the host sentence, or about an expression of the host sentence, as illustrated in (22) and (23):

(22) O Pedro emprestou a casa, pois/que/porque toda a gente the Pedro lent the house, for/that/because everybody fala disso no bairro, à sua amiga Ana. speaks about. that in.the block, to.the his friend Ana 'Pedro lent his house, since everybody speaks about that in the block, to his friend Ana.'

O Pedro emprestou a casa à sua amiga Ana. the Pedro lent the house to.the his friend Ana.

(Digo isto porque) toda a gente fala disso no bairro. say that because everybody speaks about.that in the block 'Pedro lent his house to his friend Ana. (I say that because) everybody speaks about that in the block.'

In sum, assuming that explicative clauses are parentheticals, we can explain most of their properties. 


\section{Approaches to parentheticals}

Among the proposals to account for parentheticals, two of them have deserved special interest in recent literature - the radical structural autonomy of the parenthetical constituent, among others assumed by Haegeman (1991), Huddleston et al. (2002), ${ }^{3}$ Frey (2012), Frey and Truckenbrodt (2015), and the specifying coordination approach of de Vries (2006 et seq.), recently redesigned in terms of parenthetical inclusion (de Vries 2012, Kluck 2015). ${ }^{4}$

\subsection{Parentheses as orphan constituents}

Haegeman (1991) suggests that parentheses are 'orphans', in the sense that they are not syntactically integrated into the host sentence. According to this proposal, they present radical syntactic independence with respect to the host clause, with which they only establish a notional link.

However, this analysis presents two major problems. The assumption that in Syntax the parenthetical constituent, in the case the explicative clause, is radically independent does not seem accurate. In fact, it depends on the presence of the host sentence, and becomes pragmatically odd out of that syntactic context, as shown in (24B):

$$
\begin{aligned}
& \text { A: Não sei porque é que dizes que eles estão em casa. } \\
& \text { not know why is that say that they are at home } \\
& \text { 'I don't know why you say that they are at home.' } \\
& \text { B: \#Pois/que as luzes estão acesas. } \\
& \text { For/that the lights are lighted. }
\end{aligned}
$$

Moreover, the Orphanage approach does not capture the correlation between structure and constituent linearization, and this problem cannot be overcome by assuming that the structural connection between the explicative and its host is accounted for by Late Merge. In fact, if Late Merge operates at LF, the explicative is not pronounced at PF, and if Late Merge operates at PF, the explicative is not interpreted at LF.

Thus, we reject the Orphanage analysis of explicative clauses and we argue that, as other parentheticals, they are syntactically included in the host sentence.

3. Huddleston et al. (2002) call the parentheses supplements and designate the operation that relate them to their hosts Supplementation.

4. For a discussion of recent approaches to deal with parentheticals, see Griffiths (2015). 


\subsection{Parentheses as the result of Parenthetical Merge}

de Vries (2006, 2007, 2009), Koster (2000), a.o., proposed a fourth type of coordination, apart from the copulative, disjunctive and adversative subtypes: specifying coordination. Koster (2000) uses this kind of coordination to explain a phenomenon called parallel construal, which includes standard coordination as well as constructions involving equatives and relative clauses. The author shows that these structures may be headed by different operators: conjunctions and or or, and also a colon head, ' $:$ ' In de Vries (2007, 2009), parentheses are also treated as instances of specifying coordination. In fact, the author assumes that these structures are headed by abstract conjunctions: appositives are headed by \&:, a bivalent functional head that selects two terms, and parentheticals are headed by Par, a monovalent functional head that selects only a complement.

According to de Vries (2006:239), specifying coordination has the following core properties:

a. the conjuncts are connected by a phonetically null coordinator (although, in some cases, it may be overt);

b. the conjuncts are separated in writing by a comma;

c. the second conjunct has low intonation;

d. the second conjunct is not a restrictive constituent;

e. the coordinate structure is asymmetric, in the sense that it is always the second term that specifies the first one.

Thus, accepting this proposal, the internal structure of a parenthetical expression includes a monovalent parenthetical specifying coordinator Par. For de Vries, the parenthetical constituent is b-merged with the host sentence through adjunction, forming a paratactic hierarchy. B-merge starts a new c-command domain, which explains the 'invisibility' of parentheticals in what concerns scope relationships.

Refining his analysis, de Vries (2012) considers that parentheses must be treated in terms of parenthetical inclusion. The author suggests that the traditional distinction between hypotaxis and parataxis can be captured assuming that there are two basic types of syntactic inclusion - regular inclusion, which leads to dominance relations, and parenthetical inclusion, these notions being primitives of the grammar -, arising from two kinds of Merge operations: regular Merge and Parenthetical Merge (Par-Merge). ${ }^{5}$ This explains the particular nature of the connection between the parenthesis and the host. The head Par

5. Notice that not all cases of coordination seem to beducible to parentheticals, although they are usually characterized as instances of parataxis. We will not pursue this issue here. 
triggers the application of Par-Merge, leading to Par-inclusion, which starts a new c-command domain.

The representation (25) shows the syntactic structure of a sentence including a parenthetical, which derives from the Merge operations described in (26).

(25)

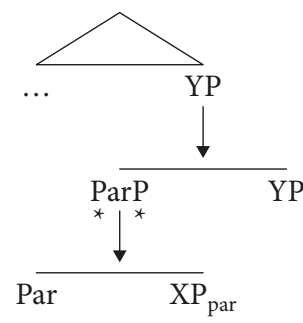

(26)

$$
\begin{aligned}
& \text { Par-Merge }\left(\text { Par, } \mathrm{XP}_{\text {par }}\right) \rightarrow \text { ParP } \\
& \text { Merge }(\text { ParP, YP }) \rightarrow \text { YP }
\end{aligned}
$$

As we can see in (25), ParP is included in YP, the host constituent. In turn, $\mathrm{XP}_{\text {par }}$, the parenthetical constituent, is embedded in the parenthetical phrase ParP. This embedding allows the required c-command effects, since there is regular inclusion in the host YP, but there is Par-inclusion within ParP, which blocks c-command from the host into the parenthetical clause.

Since $\mathrm{XP}_{\text {par }}$ is marked as parenthetical in Syntax, the phonological component receives an instruction to start a new intonational phrase. Besides, being embedded in the host, the parenthetical is interpreted as secondary information at the level of semantic interpretation.

\section{Explicative clauses as a case of parenthetical inclusion}

The idea that explicative clauses have a specifying value seems to be reasonable, since they express the speakers' motivation to utter the proposition in the host clause, as shown in (27)-(28):

(27) Ela saiu de casa à pressa, pois/que/porque as luzes she left of home to.the hurry, for/that/because the lights estão acesas.

are lighted

'She left home in a hurry, for/because the lights are on.'

(28) Ela saiu de casa à pressa: as luzes estão acesas. she left of home to.the hurry: the lights are lighted 'She left home in a hurry: the lights are on.' 
Moreover, explicative clauses, as other expressions, may iterate, as shown in (29):

(29) Ela esteve a pintar, que tem as mãos sujas, que até tem she has been painting, that has the hands dirty, that even has tinta no cabelo. paint in.the hair 'She has been painting, because her hands are dirty, because she even got paint in her hair.'

As mentioned above, Par-inclusion starts a new c-command domain. In explicatives there is blocking of c-command from the host clause. This accounts, for example, for the lack of scope of the host sentence negation over the explicative clause illustrated in (30):

(30) Ela não saiu, pois/que/porque as luzes estão acesas. she not left, for/that/because the lights are lighted 'She did not leave, because the lights are on.'

This also explains the absence of Principle $\mathrm{C}$ effects in the explicative clause, potentially determined by the host clause.

(31) Ela $a_{i}$ saiu à pressa, pois/que/porque a Maria $a_{i}$ nunca deixa she left in.the hurry, for/that/because the Maria never leaves as luzes acesas. the lights lighted

'She left in a hurry, because Maria never leaves the lights on.'

Summarizing, the empirical data presented in the previous sections indicate that explicative clauses are a specific case of parentheses. The approach in terms of Par-inclusion allows us to account for the paratactic nexus they establish with the host sentence, while keeping the evidence that, in the local domain headed by the explicative connector, they (still) behave as subordinate clauses. In addition, Parinclusion accounts for the syntactic merge of the explicative clause into the host clause, while it captures its "loose" integration in it.

\section{The position of explicative clauses inside the host sentence}

The position occupied by explicative clauses introduced by pois, que and porque inside their host sentences is related to their discursive import as expressions exhibiting a specifying value. 
The specifying value requires that the specifying expression follows the specified one. As already mentioned, in the case of explicative clauses, they specify a justification for the proposition in the host clause. In some cases, the justification may also focus on one element of this proposition. As a consequence, explicative clauses may not precede the expression which is the target of the specification. This explains why explicative clauses may not precede their hosts, which means that they may not be fronted, as shown in (32b):

(32) a. O Pedro está constipado, pois/que/porque espirrou the Pedro is cold for/that/because sneezed

durante toda a noite.

during all the night

'Pedro has got a cold, because he sneezed all night long.'

b. ${ }^{*}$ Pois/que/porque espirrou durante toda a noite, o for/that/because sneezed during all the night, the

Pedro está constipado.

Pedro is cold

'Because he sneezed all night long, Pedro has got a cold'

In fact, since explicative clauses must be preceded by the target specified expression, if the whole predication of the host sentence is the target of the specification, the explicative clause must occur in the right periphery, as in (33a), which contrasts with (33b) and (33c):

(33) a. Ela saiu de casa à pressa, pois/que/porque she left of home to.the hurry, for/that/because

as luzes estão acesas.

the lights are lighted

'She left home in a hurry, because the lights are on'

b. ??Ela, pois/que/porque as luzes estão acesas, saiu she, for/that/because the lights are lighted, left

de casa à pressa.

of home to.the hurry

'She, because the lights are on, left home in a hurry.'

c. ??Ela saiu, pois/que/porque as luzes estão acesas, she left, for/that/because the lights are lighted, de casa à pressa of home to.the hurry

'She left, because the lights are on, home in a hurry'. 
If a particular element of the host sentence is the target of the specification, it must precede the explicative. In this case, the explicative clause may be interpolated, as in (34b) and (34c), where it is related to the expression 'o João':

a. O João era incapaz de tal coisa, pois/que/porque the João was incapable of such thing for/that/because eu conheço-o bem.

I know him.CL well

'John would be incapable of such a thing, because I know him well.'

b. O João, pois/que/porque eu conheço-o bem, the João, for/that/because I know him.CL well, era incapaz de tal coisa. was incapable of such thing 'João, because I know him well, would be incapable of such a thing.'

c. O João era, pois/que/porque eu conheço-o bem, the João was, for/that/because I know him.CL well incapaz de tal coisa. incapable of such thing 'João would be, because I know him well, incapable of such a thing.'

As stated above, depending on the expression with which it is associated, explicative clauses may be appended only at the right periphery of the host sentence or also inside the host, i.e. interpolated. Next, we present the structural configurations that correspond to each one of these cases.

When the explicative clause occurs in the right periphery, it is adjoined to the host sentence, as illustrated in (36), ${ }^{6}$ for the sentence in (35):

Ela está em casa, pois/que/porque as luzes estão acesas. she is at home, for/that/because the lights are lighted 'She is at home, because the lights are on.'

6. A reviewer questions us about the category, $\mathrm{CP}$ or $\mathrm{vP}$, to which the explicative clause is right adjoined when it modifies the whole host sentence. We assume that in this case the explicative is Par-merged to $\mathrm{CP}$, the complete propositional phase, not to vP, the phase that denotes just the predicative content of the sentence. However, further empirical evidence would be required to evaluate the adequacy of each one of these options. 
(36)



Sentence (37) illustrates the possibility of the explicative clause to be interpolated. Since, in this case, it is related to the verb of the host sentence (alugaram 'rent'), the explicative adjoins to $\mathrm{vP}$, as in (38):

(37) Eles alugaram, pois/que/porque eu vi, a casa aos amigos. they rent for/that/because I saw, the house to.the friends 'They rent, because I saw it, the house to their friends.'

(38)

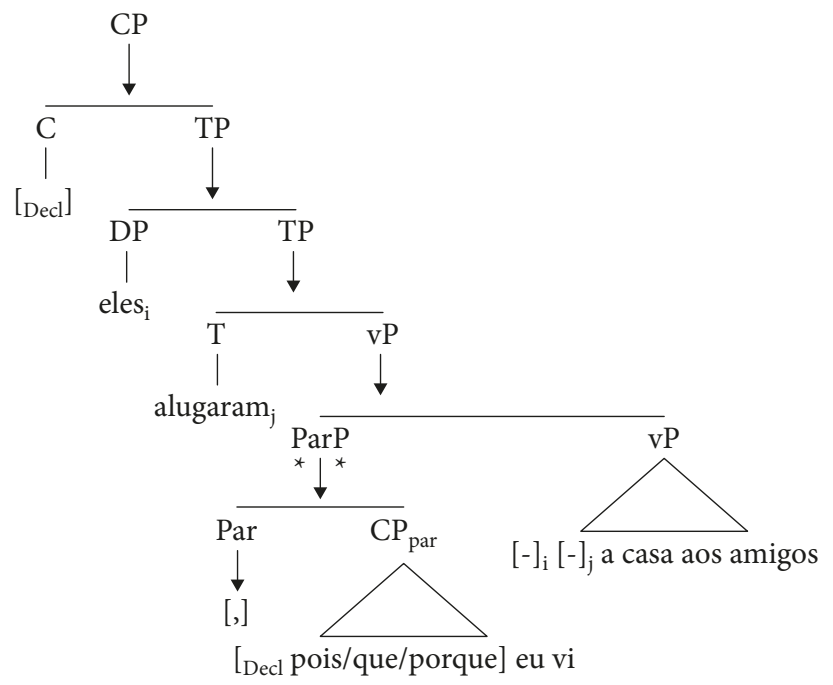

In sum, the intrinsic specifying value of these explicative clauses is apparently the cause of their placement after the constituent they specify. This property distinguishes these explicatives from others, as for instance those headed by uma vez que 'once', and já que 'since', which denote a situation, taken by the speaker as presupposed knowledge. 


\section{Concluding remarks}

The treatment of parenthetical expressions as the result of a specific operation of Merge - Parenthetical Merge - is particularly appealing to account for explicative clauses in European Portuguese. This analysis allows us to conciliate the evidence that explicative clauses initiated by pois 'for', que 'that/because' and porque 'because' present a double status: within the local domain they head, these connectors behave like complementizers and determine the finiteness of the sentence over which they have scope; within the host sentence, explicative clauses behave like parentheticals.

In addition, this approach allows us to assign a syntactic structure to parentheticals, which overtly relates the parenthetical and the host sentence.

\section{References}

Bechara, Evanildo. 1999. Moderna Gramática Portuguesa. Rio de Janeiro: Lucerna.

Bello, Andrés. 1847. Gramática de la lengua castellana. Tenerife: Aula de Cultura, 1981.

Colaço, Madalena and Gabriela Matos. 2015. "A natureza paratática das causais explicativas em português". In XXXI Encontro Nacional da Associação Portuguesa de Linguística. Textos Selecionados, ed.by António Moreno, Fátima Silva and João Veloso, 175-193. Porto: Associação Portuguesa de Linguística.

Cunha, Celso and Luís-Filipe Cintra. 1984. Nova Gramática do Português Contemporâneo. Lisboa: Edições João Sá da Costa.

Déhé, Nicole and Yordanka Kavalova. 2007. "Parentheticals: An Introduction". In Parentheticals, ed. by Déhé, Nicole and Yordanka Kavalova, 1-22. Amsterdam/Philadelphia: John Benjamins. doi:10.1075/la.106.03deh

Frey, Werner. 2012. "On two types of adverbial clauses allowing root-phenomena". In Main Clause Phenomena: New Horizons, ed. by Lobke Aelbrecht, Liliane Haegeman and Rachel Nye, 405-429. Amsterdam: John Benjamins. doi:10.1075/la.190.18fre

Frey, Werner and Hubert Truckenbrodt. 2015. "Syntactic and prosodic integration and disintegration in peripheral adverbial clauses and in right dislocation/afterthought". In Syntactic Complexity across Interfaces, ed. by Andreas Trotzke and Josef Bayer, 75-106. Berlin: Mouton de Gruyter.

Frota, Sónia. 2000. Prosody and Focus in European Portuguese. Phonological Phrasing and Intonation. New York NY: Garland.

Galán Rodriguez, Carmen. 1999. "La subordinación causal y final”. In Gramática Descriptiva de la Lengua Española, ed. by Bosque, Ignacio and Violeta Demonte, 3597-3642. Madrid: Espasa Calpe.

Giusti, Giuliana. 1991. "Frasiavverbialli: temporalli, causali e consecutive". In Grande grammatica italiana di consultazione, ed. by Renzi, Lorenzo and Giampaolo Salvi, 2.2, 738-751. Bologna: Il Molino.

Grevisse, Maurice. 1993. Le Bon Usage- Grammaire française. Refondued par André Goosse, 13th edition revised. Paris: Duculot. 
Griffiths, James. 2015. On appositives. Ph.D. Dissertation, University of Groningen. Utrecht: LOT Dissertation Series, no.389.

Haegeman, Liliane. 1991. "Parenthetical adverbials: The radical orphanage approach". In Aspects of Modern English: Papers Presented to Masatomo Ukaji on his 60th birthday, ed. by Shuki Chiba, Akira Ogawa, Yasuaki Fuiwara, Norio Yamada, Osamu Koma and Takao Yagi, 232-254. Tokyo: Kaitakushi.

Huddleston, Rodney, John Payne and Peter Peterson. 2002. "Coordination and Supplementation". In The Cambridge Grammar of the English Language, ed. by Rodney Huddleston, and Geoffrey Pullum, 1273-1351.Cambridge: Cambridge University Press.

Kluck, Marlies. 2015. "On representing anchored parentheses in syntax". In Syntactic Complexity across Interfaces, ed. by Andreas Trotzkeand Josef Bayer, 107-136. Berlin: Mouton de Gruyter.

Koster, Jan. 2000. Extraposition as Parallel Construal. University of Groningen. http://www.let. rug.nl/koster/papers/parallel.pdf

Lobo, Maria. 2003. Aspectos da Sintaxe das orações subordinadas adverbiais do Português. Ph.D. Thesis. Lisboa: Universidade Nova de Lisboa.

Lobo, Maria. 2013. "Subordinação adverbial". In Gramática do Português, ed. by Raposo, Eduardo, M. Fernanda Nascimento, M. Antónia Mota, Luísa Segura and Amália Mendes, vol II, 1979-2057. Lisboa: Fundação Calouste Gulbenkian.

Lopes, Helena. 2004. Aspectos Sintácticos, Semânticos e Pragmáticos das Construções Causais Contributo para uma Reflexão sobre o Ensino da Gramática. Ph.D. Thesis, Porto: Universidade do Porto.

Macário Lopes, Ana Cristina. 2012. "Contributos para uma análise Semântico-pragmática das causais de enunciação no português europeu contemporâneo”. Alfa, São Paulo, 56 (2): 451-468.

Matos, Gabriela. 2003. "Estruturas de Coordenação". In Gramática da Língua Portuguesa, ed. by Mateus M. Helena, Ana Brito, Inês Duarte, Isabel Faria, Sónia Frota, Gabriela Matos, Fátima Oliveira, Marina Vigário and Alina Villalva, 229-259. Lisboa: Editorial Caminho.

Matos, Gabriela. 2004. "Coordenação Frásica vs. Subordinação Adverbial”. In Actas do XIX Encontro Nacional da Associação Portuguesa de Linguística, ed. by Freitas, Tiago and Amália Mendes, 555-567. Lisboa: Associação Portuguesa de Linguística.

Matos, Gabriela and Madalena Colaço. 2010. "A coordenação parentética como uma instância de adjunção". Textos Seleccionados do XXV Encontro Nacional da Associação Portuguesa de Linguística, 2009, 607-622. Porto: Associação Portuguesa de Linguística.

Matos, Gabriela and Eduardo Raposo. 2013. "Estruturas de coordenação". In Gramática do português, ed. by Raposo, Eduardo, M. Fernanda Nascimento, M. Antónia Mota, Luísa Segura and Amália Mendes, vol. II, 1761-1817. Lisboa: Fundação Calouste Gulbenkian.

Peres, João and Salvador Mascarenhas. 2006. "Notes on sentential connections (predominantly) in Portuguese". Journal of Portuguese Linguistics 5 (1): 775-567.

Piot, Mireille. 1988. « Coordination-subordination: une définition générale ». Langue Française, 77: 3-36. doi:10.3406/lfr.1988.4734

Quirk, Randolph, Sidney Greenbaum, Geoffry Leech and Jan Svartvik. 1985. A Comprehensive Grammar of the English Language. London: Longman.

Real Academía Española.1931. Gramática de la lengua española. Madrid: Espasa Calpe.

Real Academía Española. 1973. Esbozo de una nueva gramática de la lengua española. Madrid: Espasa Calpe. 
Said Ali, Manuel. 1931. Gramática Histórica da língua Portuguesa. São Paulo: Edições Melhoramentos, 1964.

Santos Río, Luis. 1982. "Reflexiones sobre la expresión de la causa en castellano”. Studia Philologia Salmanticensia, 6: 231-277.

de Vries, Mark. 2006. “The Syntax of Appositive Relativization: On Specifying Coordination, False Free Relatives and Promotion". Linguistic Inquiry 37 (2): 229-270. doi:10.1162/ling.2006.37.2.229

de Vries, Mark. 2007. "Parentheses as B-merged adverbial phrases". In Parentheticals, ed. by Déhé, Nicole and Yordanka Kavalova, 203-234. Amsterdam/Philadelphia: John Benjamins. doi:10.1075/la.106.11vri

de Vries, Mark. 2009. "Specifying Coordination: An Investigation into the Syntax of Dislocation, Extraposition and Parenthesis". In Language and Linguistics: Emerging Trends, ed. by Cynthia R. Dreyer, 37-98, New York: Nova.

de Vries, Mark. 2012. Unconventional Mergers. In Ways of Structure Building, ed. by Myriam Uribe-Etxebarria and Vidal Valmala, 143-166. Oxford: Oxford University Press.

doi:10.1093/acprof:oso/9780199644933.003.0007 